\title{
The Analytic Cognitive Style and Conspiracy Mentality as Predictors of Conspiracy Beliefs
}

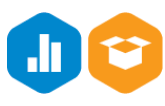

Eva Ballová Mikušková iD

Institute of Experimental Psychology, Center of Social and Psychological Sciences, Slovak Academy of Sciences, Bratislava, Slovak Republic

The study aims to verify the level of conspiracy beliefs and the relationship of conspiracy beliefs with the conspiracy mentality and analytic cognitive style. A total of 470 participants ( $49.4 \%$ women) aged 18-73 years old $(M=42.35 ; S D=13.12)$ participated in the study. They completed the Slovak Conspiracy Belief Scale, the Conspiracy Mentality Questionnaire, the Cognitive Reflection Test, the Jellybean Task, the Rational-Experiential Inventory, and the Master Rationality Motive Scale. Conspiracy beliefs were at the midpoint level, and the beliefs that participants most trusted were identified. Although conspiracy beliefs correlated negatively with cognitive reflection, denominator neglect and motivation for rational integration and positively with conspiracy mentality and preference for experiential thinking, only conspiracy mentality, cognitive reflection and motivation for rational integration were significant predictors of conspiracy beliefs.

Key words: conspiracy beliefs, conspiracy mentality, cognitive reflection, motivation for rational integration, thinking preferences

Conspiracy theories - theories about a secret plot of two or more actors explaining the background of some significant social and/or political events (Douglas, Uscinski, et al., 2019) - have accompanied humankind since time immemorial (Buttler \& Knight, 2019; Douglas, Sutton, et al., 2019; Uscinski \& Paret, 2014; van Prooijen \& Song, 2020), are widespread among people of all cultures (Buttler \& Knight, 2019; Renard, 2020; Swami \& Furnham, 2012; Uscinski, 2019a; van Prooijen \& Song, 2020), and seem to be on the rise. Several global studies have pointed to the alarming spread of conspiracy theories and hoaxes around the world (even before 2020 before the spread of conspiracy theories related to COVID-19; e.g., Globsec, 2017; Globsec,

\footnotetext{
Correspondence concerning this article should be addressed to Eva Ballová Mikušková, Institute of Experimental Psychology, Center of Social and Psychological Sciences, Slovak Academy of Sciences, Dúbravská cesta 9, 84104 Bratislava, Slovak Republic. E-mail: expsebal@savba.sk

Supplementary information for this article is available at https://journals.savba.sk/index.php/studiapsychologica/article/view/202/66
}

Received August 11, 2020 
2020; Jensen, 2013; Newport \& Strausberg, 2001).

The belief that a conspiracy theory is true is called a conspiracy belief (Uscinski, 2019b), and people can hold many conspiracy beliefs, even conflicting ones (Wood et al., 2012), at the same time. Such a tendency to see events as the product of conspiracies is considered a latent trait or a disposition to conspiracy thinking, conspiracy ideation or conspiracy mentality (Bruder et al., 2013; Dyrendal et al., 2017; Uscinski, 2019b). In other words, when someone believes in one or several conspiracy theories, the likelihood that they will believe in yet another one increases (e.g., Douglas et al., 2017; Imhoff \& Bruder, 2014; Swami et al., 2010, 2011; Uscinski, 2019b). A possible explanation of such a cumulative effect of conspiracy thinking is that although conspiracy beliefs emerge as a response to a stressful and uncertain situation and crisis (e.g., Grzesiak-Feldman, 2013; Swami et al., 2016; van Prooijen \& Douglas, 2017; an Prooijen \& van Vugt, 2018), they do not reduce the feeling of threat, the experience of a lack of control, powerlessness or anxiety; on the contrary, conspiracy beliefs encourage the growth of negative feelings and stimulate the endorsement of further conspiracy beliefs (van Prooijen, 2020).

Despite a long history of conspiracy theories, research on conspiracies has been increasing only in the last decades, and a systematic review of psychological research on conspiracy beliefs was conducted only in recent years (Douglas, Uscinski, et al., 2019). On one hand, conspiracy beliefs help keep people alert to transparency in public affairs and government and open issues for discussion (Clarke, 2002; Douglas, Uscinski, et al., 2019; Swami et al., 2011). On the other hand, there are more serious disadvantages of conspiracy beliefs. People believing in conspiracy theories may reject scientific consensus, for example, concerning vaccination or climate change (Douglas, Uscinski, et al., 2019; Jolley \& Douglas, 2014). Conspiracy beliefs induce prejudice toward particular groups (Pasek et al., 2014), reduce the intention to vote, undermine political trust and are related to radicalization (Bartlett \& Miller, 2010). Conspiracy beliefs play an important role both in personal and public life: from attitude toward vaccination and evidence-based medicine to results of a parliamentary election (for example, the election of a Neo-Nazi party to parliament in 2016 as well as in 2020 in Slovakia).

The negative consequences of conspiracy beliefs raise the question of how conspiracy beliefs can be reduced and whether development of some specific skills or type of thinking can help. From this point of view, research on the effect of analytic thinking on reducing conspiracy beliefs seemed to be a promising approach. Analytic thinking (the Type 2 processes in the dual-process theory) is deliberative, slow and effortful (e.g., Barbey \& Sloman, 2007; Evans, 2008, 2010) and could override autonomous, fast and intuitive reasoning (the Type 1 processes). In a similar way - through the override process analytic thinking can reduce the endorsement of unwarranted beliefs, for example, superstitious and paranormal beliefs (Pennycook et al., 2012), fake news (Pennycook \& Rand, 2019, 2020), pseudo-profound bullshit (Čavojová et al., 2018; Pennycook et al., 2015; Pennycook \& Rand, 2020) or conspiracy beliefs. Several studies examining the association of thinking disposition and conspiracy beliefs showed that analytic thinking helps to reduce conspiracy beliefs (Orosz et al., 2016; Ståhl \& van Prooijen, 2018 - Study 1; Swami et al., 2014; Swami \& Barron, 2020), and intuitive thinking is associated with an increase in conspiracy beliefs (Pytlik et al., 2020; Stojanov \& Halberstadt, 2020; Swami et al., 2014).

In Slovakia, the psychology of conspiracy beliefs has been examined in a few studies (e.g., Ballová Mikušková, 2018; Čavojová et 
al., 2018; Halama, 2019). One study with conspiracy beliefs as the main variable (Ballová Mikušková, 2018) focused on the description of conspiracy beliefs specific to future teachers and the relation between cognitive abilities and conspiracy beliefs. Such beliefs were examined using a sample of university students who showed midpoint agreement with conspiracy theories. As in other studies (Orosz et al., 2016; Ståhl \& van Prooijen, 2018 - Study 1; Swami et al., 2014; Swami \& Barron, 2020), conspiracy beliefs were negatively associated with the analytic cognitive style. The strength of the study was the culturally specific measurement of conspiracy beliefs (the Slovak Conspiracy Belief Scale) and the main limitation was the specific student sample. Therefore, the aim of the present study was the replication of a previous Slovak study (Ballová Mikušková, 2018) on a non-student sample ${ }^{1}$. The hypotheses were:

- participants show a midpoint level of conspiracy beliefs, as in previous studies on Slovak samples (Ballová Mikušková, 2018; Čavojová et al., 2018),

- thinking disposition will predict the endorsement of conspiracy beliefs: the analytic cognitive style will predict lower conspiracy beliefs, and the intuitive cognitive style will predict stronger endorsement of conspiracy beliefs (Orosz et al., 2016; Pytlik et al., 2020;

${ }^{1}$ The original aim of the present study was to replicate the results of Ballová Mikušková (2018) study on non-student and student samples and comparison of these two samples; data from 470 non-students (the sample of the present study) and 169 undergraduates were analyzed. Being notified by the reviewers and taking into account that the student sample was limited (students of one field collected by chance) in a generalization of conclusions, in the present version of the study, the aim was changed to "the replication of a previous Slovak study (Ballová Mikušková, 2018) on a non-student sample" and only data from the non-student sample were analyzed. The methods and results related to the original version of the study including the analyses of student sample data, as well as a brief comparison with present findings, are in the Online Appendix.
Ståhl \& van Prooijen, 2018; Stojanov \& Halberstadt, 2020; Swami et al., 2014; Swami \& Barron, 2020),

- conspiracy thinking (mentality) would be a strong predictor of conspiracy beliefs (Bruder et al., 2013; Dyrendal et al., 2017; Imhoff \& Bruder, 2014; Uscinski, 2019b).

\section{Methods}

The present study was confirmatory. All data are publicly available on the Open Science Framework (https://osf.io/y3vz8/). The study was conducted in accordance with the provisions of the Declaration of Helsinki and according to the American Psychological Association standards.

\section{Participants and Procedure}

The sample size was calculated using an alpha of 0.05 , a power of 0.80 and an effect size of 0.25 , yielding a sample of $400+10 \%$. Data collection was to be terminated after reaching the desired number (440). Participants were recruited from the pool of a recruitment agency (complying with the ESOMAR international code) based on the following criteria: non-students, age $(18+)$, sex (balanced ratio), education (balanced ratio of secondary school education and university education). A total of 470 participants (49.4\% women) aged $18-73$ years old $(M=42.35 ; S D=13.12)$ participated in the study.

The data were collected in 2018 through an online survey hosted on Qualtrics. Participation was voluntary and anonymous, and the study was carried out following ethical principles introduced by the American Psychological Association. The data collected were only those relevant to the research purpose, and the data were anonymized so they could not be traced. All measures, conditions, data exclusions and sample-size calculation are reported in the study. 


\section{Measurement}

After reading and signing the informed consent form, the participants completed the Slovak Conspiracy Belief Scale, the Cognitive Reflection Test, the Jellybean Task, the Conspiracy Mentality Questionnaire, the Rational-Experiential Inventory and the Master Rationality Motive Scale. The materials included two control questions to eliminate random responses (e.g., participants had to click on a specific option: 'Now click response 4.'). If a participant gave the wrong response to the control questions their participation in the research was terminated.

\section{Conspiracy Beliefs and Mentality}

Conspiracy beliefs. To measure conspiracy beliefs, the Conspiracy Beliefs subscale from the Slovak Conspiracy Belief Scale (SCBS, Ballová Mikušková, 2018) was used. Participants expressed their agreement with 15 items concerning existing conspiracy theories (SCBS-C; seven items reflect specifically Slovak conspiracy theories and eight reflect generally well-known conspiracy theories $)$ on a 6 -point scale $(1=$ totally disagree, 6 = totally agree); the average score was computed, with a higher score indicating stronger conspiracy beliefs.

Conspiracy mentality. The Conspiracy Mentality Questionnaire (CMQ) was developed by Bruder et al. (2013; Slovak version prepared by Ballová Mikušková, 2018) and measures the general tendency to believe in conspiracies or to have a conspiracy mentality. The designers found that a conspiracy mentality predicted endorsement of specific conspiracy theories. Participants rated five items - general statements capturing a conspirational view of world events - on a 6-point Likerttype scale $(1=$ totally disagree, $6=$ totally agree); the average score was computed, and a higher score indicated a stronger conspiracy mentality.

\section{Analytic Cognitive Style}

Cognitive reflection. The six items from the Cognitive Reflection Test (Frederick, 2005; Toplak et al., 2013; Slovak version prepared by Kostovičová et al., 2013) were used to measure cognitive reflection - the ability to override an initial intuitive and incorrect response to arrive at the correct solution. Correct answers were assigned 1 point and the sum of the CRT was computed from 6 items; a higher score indicated higher cognitive reflection.

Resistance to denominator neglect. Resistance to denominator neglect (ratio-bias phenomenon) was measured as the expression of analytic thinking. The text version of the Jellybean Task (JBT; Kirkpatrick \& Epstein, 1992; Slovak version prepared by Ballová Mikušková, 2015) was used, and a total of six problems were modeled: three problems with equal probabilities and three problems with unequal probabilities, in which participants had to choose between one of two combinations of red and white jellybeans in each problem. Problems with unequal probabilities were set up as the choice between the "small" urn (10 jellybeans with a $10 \%$ probability of pulling out a red jellybean), or the "large" urn (100 jellybeans with a $6 \%, 7 \%$, and $8 \%$ probability of pulling out a red jellybean). The problems with equal probabilities were set up as the choice between the "small" (10 jellybeans) and "large" urn (100 jellybeans) both with a 6\%, 7\%, and $8 \%$ probability. Participants were instructed to choose the combination they thought gave them a higher chance of pulling out a red jellybean. Correct answers were assigned 1 point; the sum of correct responses in the items with equal and unequal probabilities was computed, with a higher value indicating a more analytic cognitive style. 
Thinking preferences. The Rational-Experiential Inventory (REI) is based on the Cognitive-Experiential Self-Theory (e.g., Epstein, 2003) and consists of two previously separate scales - Need for Cognition (the basis of the Rationality scale) and Faith in Intuition (the basis of the Experientiality scale). It measures two thinking styles and has four dimensions: Rational Engagement and Rational Ability (together they comprise the Rational Thinking Style, 20 items), and Experiential Engagement and Experiential Ability (together they comprise the Experiential Thinking Style, 20 items). Pacini and Epstein (1999) developed several versions of the REI. In the present study, the short version of the REI (10 Rational Thinking Style items, 10 Experiential Thinking Style items; Slovak version prepared by Ballová Mikušková, Hanák, \& Čavojová, 2015) was used. Participants rated the items on a 6-point Likert-type scale ( 1 = totally disagree, $6=$ totally agree); the average score was computed for preference for rational/ experiential thinking, and a higher score indicates a stronger preference for rational/ experiential thinking.

The motive for rational integration. The Master Rationality Motive Scale (MRMS; Stanovich, 2011; Slovak version prepared by Ballová Mikušková, 2015) measures the construct of rational motivation (felt need for rational integration) - the motive for rational integration. It combines questions from some other scales, mainly measuring cognitive styles or personality. The MRMS consists of 15 questions; participants evaluated all the items on a 6-point Likert scale ( $1=$ totally disagree, $6=$ totally agree); the average score was computed, and a high score indicated motivation for rational integration.

\section{Results}

\section{Descriptive Statistics and Differences}

The descriptive statistics of all the used measures are in Table 1 . The internal consisten-

Table 1 Descriptive statistics and internal consistency of all variables

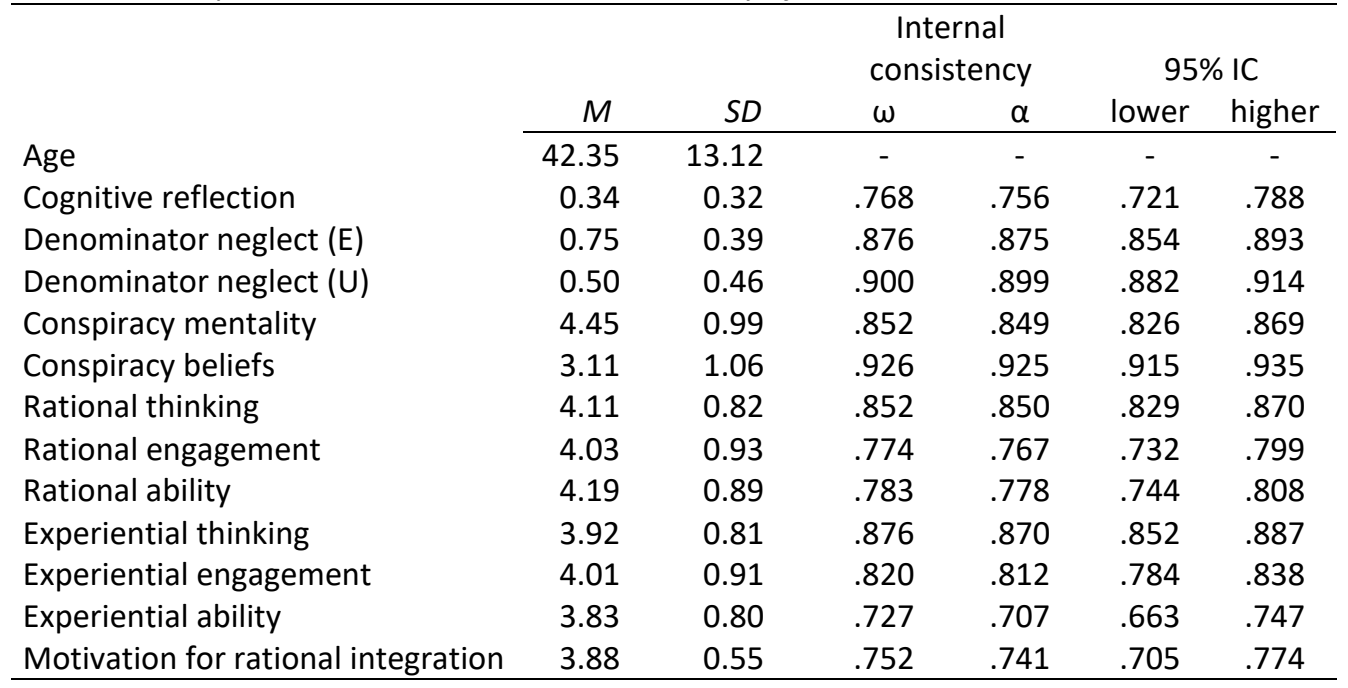

Note. $N=470$, denominator neglect $(\mathrm{E})$ - tasks with equal probability, denominator neglect (U) - tasks with unequal probability 
cy of all the used measures was satisfactory, with McDonald's $\omega$ ranging from .727 to .926 (Cronbach's a ranged from .707 to .925). Conspiracy beliefs of participants were compared (one-sample $t$-test) to the mean conspiracy beliefs score of students in a previous study $(N=275 ; M=3.21 ; S D=0.80)$ : participants in the present study had significantly lower conspiracy beliefs than those in the previous study ( $t=2.102 ; p=.036 ; d=0.097)$. Second, the mean of conspiracy beliefs was at the midpoint level (the range was 1-6 points and $M=3.11 ; S D=1.06$ ).

All conspiracy theories (SCBS) as well as items of the Conspiracy Mentality Questionnaire were sorted by mean to find out what theories people believe (Table 2). On the Slovak Conspiracy Beliefs Scale, participants believed the most (above the mean) that doctors prescribe many harmful medications and antibiotics because they are paid by pharmaceutical companies that profit from manufacturing new medications $(M=3.84 ; S D=1.53)$, that discrimination against alternative medicine is due to pharmaceutical companies wanting to hide medications' ineffectiveness $(M=3.80$; $S D=1.58)$, that the source of all problems are lobbyist groups threatening our future in the name of humanism by supporting Muslim immigrants and the Roma minority $(M=3.66 ; S D=1.57)$, that the 1989 revolution had been prepared since June 1988 and it became an instrument of the internal political power struggle $(M=3.58$; $S D=1.48)$, that some so-called independent newspapers are under the governance of certain secret groups supported by other countries in order to brainwash and control people $(M=3.43 ; S D=1.59)$, and that the American government was behind the 9/11 attacks in order to start a war with the Muslim world and gain cheap access to power and oil in that part of the world $(M=3.34$; $S D=1.65$ ).

In the Conspiracy Mentality Questionnaire, participants believed the most (above the mean 4.45 ) that many very important things happen in the world, which the public is never informed about, and that politicians usually do not tell the true motives for their decisions.

Table 2 Endorsement rate for all conspiracy beliefs

\begin{tabular}{|c|c|c|c|c|c|}
\hline & $M$ & $S D$ & $\mathrm{Md}$ & Mo & $\begin{array}{c}\text { agreement } \\
(\%)\end{array}$ \\
\hline $\begin{array}{l}\text { SCBS } \\
\text { Doctors prescribe many harmful medications and antibiotics because } \\
\text { they are paid by large pharmaceutical companies that profit from } \\
\text { producing new, unnecessary medications. }\end{array}$ & 3.84 & 1.53 & 4 & 4 & 37.87 \\
\hline $\begin{array}{l}\text { Discrimination of alternative medicine is caused by large pharmaceutical } \\
\text { companies in order to hide that many medications are ineffective or less } \\
\text { effective than alternative treatments. }\end{array}$ & 3.80 & 1.58 & 4 & 4 & 36.59 \\
\hline $\begin{array}{l}\text { The source of our problems are various lobbyist groups that threaten } \\
\text { our future in the name of humanism, e.g. by supporting Muslim } \\
\text { immigrants and the Roma minority. }\end{array}$ & 3.66 & 1.57 & 4 & 4 & 31.07 \\
\hline $\begin{array}{l}\text { The } 1989 \text { revolution had been prepared since June 1988; it was not } \\
\text { spontaneous. It became an instrument of an internal political power } \\
\text { struggle, as evidenced by the fact that the communist regime fell in all } \\
\text { countries of the former Eastern bloc almost simultaneously. }\end{array}$ & 3.58 & 1.48 & 3 & 3 & 27.87 \\
\hline
\end{tabular}


Table 2 continued

SCBS

Some of our so-called independent newspapers are under the governance of certain secret groups supported by other countries in order to brainwash and control us.

The American government was behind the 9/11 attacks in order to start a war with the Muslim world and gain cheap access to power and oil in that part of the world.

Some groups begin efforts to influence our children in school in order to raise obedient citizens who will not question orders from above.

In the past, some of our prominent politicians have been assassinated by foreign governments to keep the secret of trying to take political control of us.

There is a growing effort in our country to destroy the traditional family and Christian values through gender propaganda in schools which was produced by influential homosexuals.

There are efforts to legalize the taking of children for adoption for paying customers from the West (especially homosexuals and pedophiles).

Global warming is deliberately caused by developed countries to control and subsequently reduce the world's population.

The world should not have learnt that Princess Diana was pregnant by her lover Dodi al-Fayed, so her death was ordered by the British royal family.

The deadly HIV virus was cultivated in a CIA laboratory and along with other viruses is being spread as aerosols by airplanes in the form of vapor trails in the sky.

Global warming is a fabrication of several groups in order to halt industry in Western countries and make profit by penalties from companies who produce the so-called emissions.

Childhood vaccination is mandatory so that large pharmaceutical companies can experiment on our children and develop biological weapons.

\section{$\mathrm{CMQ}$}

I think that politicians usually do not tell us the true motives for their decisions.

I think that many very important things happen in the world which the public is never informed about.

I think that there are secret organizations that greatly influence political decisions.

I think that government agencies closely monitor all citizens.

I think that events which superficially seem to lack a connection are often the result of secret activities.

Note. Agreement - score of 5 or 6 agreement

$\begin{array}{lllll}M & S D & \text { Md } & \text { Mo }\end{array}$

$\begin{array}{lllll}3.43 & 1.59 & 3 & 3 & 28.30\end{array}$

$\begin{array}{lllll}3.34 & 1.65 & 3 & 3 & 26.81\end{array}$

$\begin{array}{lllll}3.33 & 1.50 & 3 & 3 & 23.40\end{array}$

$\begin{array}{lllll}3.19 & 1.51 & 3 & 3 & 20.63\end{array}$

$\begin{array}{lllll}3.07 & 1.69 & 3 & 1 & 23.40\end{array}$

$\begin{array}{lllll}2.96 & 1.50 & 3 & 3 & 15.54\end{array}$

$\begin{array}{lllll}2.78 & 1.54 & 3 & 1 & 15.11\end{array}$

$\begin{array}{lllll}2.66 & 1.41 & 3 & 1 & 11.70\end{array}$

$\begin{array}{lllll}2.40 & 1.40 & 2 & 1 & 9.14\end{array}$

$\begin{array}{lllll}2.38 & 1.41 & 2 & 1 & 7.87\end{array}$

$\begin{array}{lllll}2.19 & 1.35 & 2 & 1 & 6.81\end{array}$

$\begin{array}{lllll}5.07 & 1.07 & 5 & 6 & 75.1\end{array}$

$\begin{array}{llllll}4.87 & 1.14 & 5 & 6 & 65.8\end{array}$

$\begin{array}{lllll}4.30 & 1.37 & 4 & 4 & 47.1\end{array}$

$\begin{array}{lllll}4.01 & 1.33 & 4 & 4 & 38.3\end{array}$

$\begin{array}{lllll}4.00 & 1.32 & 4 & 4 & 36.6\end{array}$ 


\section{Predictors of Conspiracy Beliefs}

The mutual correlation of all the used variables are in Table 3. Conspiracy beliefs positively correlated with conspiracy mentality (CMQ) and a preference for experiential thinking (REI) and negatively with cognitive reflection (CRT), denominator neglect (JBT - items with unequal probabilities), preference for rational thinking (REI), and motivation for rational integration (MRMS).

The conspiracy mentality, cognitive reflection, resistance to denominator neglect, rational thinking preference, experiential thinking preference, and motivation for rational thinking were examined as predictors of conspiracy beliefs. First, the assumption of linear

Table 3 Correlations of conspiracy beliefs and conspiracy mentality with other variables

\begin{tabular}{|c|c|c|c|c|c|c|c|c|c|c|c|}
\hline & 1. & 2. & 3. & 4. & 5. & 6. & 7. & 8. & 9. & 10. & 11. \\
\hline \multicolumn{12}{|l|}{ 1. conspiracy beliefs } \\
\hline 2. conspiracy mentality & $.64 * * *$ & & & & & & & & & & \\
\hline 3. cognitive reflection & $-.22 * * *$ & $-.14 * *$ & & & & & & & & & \\
\hline 4. denominator neglect (E) & -.08 & -.02 & $.23 * * *$ & & & & & & & & \\
\hline 5. denominator neglect (U) & $-.15^{* *}$ & $-.13 * *$ & $.44 * * *$ & $.18^{* * *}$ & & & & & & & \\
\hline 6. rational thinking & $-.19 * * *$ & -.08 & $.30 * * *$ & $.13^{* *}$ & $.21^{* * *}$ & & & & & & \\
\hline 7. rational engagement & $-.16 * * *$ & $-.10^{*}$ & $.23 * * *$ & .08 & $.16 * * *$ & $.91^{* * *}$ & & & & & \\
\hline 8. rational ability & $-.18^{* * *}$ & -.04 & $.31 * * *$ & $.16^{* * *}$ & $.22 * * *$ & $.90 * * *$ & $* .63^{* * *}$ & & & & \\
\hline 9. experiential thinking & $.18^{* * *}$ & $.26 * * *$ & $-.20 * * *$ & -.04 & $-.19 * * *$ & .02 & .02 & .01 & & & \\
\hline $\begin{array}{l}\text { 10. experiential } \\
\text { engagement }\end{array}$ & $.19 * * *$ & $.26 * * *$ & $-.19 * * *$ & -.06 & $-.16 * * *$ & .02 & .04 & .00 & $.95 * * *$ & & \\
\hline 11. experiential ability & $.15^{* * *}$ & $.22 * * *$ & $-.20 * * *$ & -.02 & $-.19 * * *$ & .01 & .00 & .02 & $.94 * * *$ & $.79 * * *$ & \\
\hline $\begin{array}{l}\text { 12. motivation for rational } \\
\text { integration }\end{array}$ & $-.28 * * *$ & $-.14^{* *}$ & $.14^{* *}$ & $.11^{*}$ & $.22^{* * *}$ & $.54 * * *$ & $.40 * * *$ & $.57 * * *$ & $-.28 * * *$ & $-.28 * * *$ & $-.24^{* * *}$ \\
\hline
\end{tabular}

Table 4 Summary of linear regression analysis for variables predicting conspiracy beliefs

\begin{tabular}{lccccccc}
\hline & \multicolumn{7}{c}{ Conspiracy beliefs } \\
\cline { 2 - 8 } & \multicolumn{1}{c}{ B } & SE & $b$ & $t$ & $p$ & Tolerance & VIF \\
\hline Predictors & 1.872 & 0.396 & & 4.733 & $<.001$ & & \\
Constant) & 0.650 & 0.039 & 0.607 & 16.857 & $<.001$ & 0.743 & 1.346 \\
Conspiracy mentality & -0.310 & 0.133 & -0.093 & -2.322 & .021 & 0.784 & 1.276 \\
Denominator neglect & 0.024 & 0.091 & 0.010 & 0.264 & .792 & 0.640 & 1.564 \\
Rational thinking & -0.029 & 0.055 & -0.023 & -0.529 & .597 & 0.806 & 1.241 \\
Experiential thinking & -0.047 & 0.050 & -0.036 & -0.934 & .351 & 0.626 & 1.597 \\
Motivation for & -0.325 & 0.084 & -0.170 & -3.897 & $<.001$ & 0.920 & 1.087 \\
rational integration & \multicolumn{7}{c}{$F(6,463)=62.705, p<.001, R^{2}=.448$} \\
\end{tabular}


regression was tested: A P-P plot showed that residuals of the regression followed a normal distribution and are equally distributed, and the variance inflation factor (VIF) values were between 1.087 and 1.597 - the predictor variables were not highly correlated with each other. The assumption of linear regression was met, and the linear regression was conducted (Table 4).

Regression statistics are in Table 4. The linear regression revealed that only conspiracy mentality, cognitive reflection, and motivation for rational integration contributed significantly to the regression model $(F(6,463)=$ 62.705, $\left.p<.001, R^{2}=.448\right)$.

\section{Discussion}

The research on conspiracy belief predictors revealed analytic thinking as a factor reducing conspiracy beliefs (Ballová Mikušková, 2018; Orosz et al., 2016; Pytlik et al., 2020; Ståhl \& van Prooijen, 2018; Stojanov \& Halberstadt, 2020) and results of the present study replicated the previous findings (Ballová Mikušková, 2018): Slovaks had a midpoint level of conspiracy beliefs and an analytic cognitive style - cognitive reflection and motivation for rational integration - had a negative effect on conspiracy beliefs. Moreover, in line with the findings of other studies and the definition of conspiracy mentality as a propensity to general conspiracy beliefs (e.g., Bruder et al., 2013; Dyrendal et al., 2017; Imhoff \& Bruder, 2014; Lantian et al., 2016), a conspiracy mentality was the strongest predictor of conspiracy belief.

The people in our study believed mostly in the unnecessary prescribing of medications and antibiotics for the profit of pharmaceutical companies; in discrimination against alternative medicines by pharmaceutical companies hiding their own medications' ineffectiveness; in lobbyist groups threatening us by supporting
Muslim immigrants and the Roma minority; that the 1989 revolution had been prepared since June 1988 and became an instrument of the internal political power struggle; that some so-called independent newspapers are under the governance of certain secret groups; and that the American government was behind the 9/11 attacks. The data for the present study were collected in 2018, and conspiracy theories have changed considerably to date due to the spread of the coronavirus SARS-CoV-2 (and COVID-19) since the end of 2019.

In the present study, conspiracy beliefs were predicted by a lower level of cognitive reflection and motivation for rational integration. Cognitive reflection is commonly used as a measure of an analytic cognitive style and was revealed to be a negative predictor of unwarranted beliefs (e.g., Pennycook et al., 2012; Pennycook \& Rand, 2019; Rizeq et al., 2020; Ståhl \& van Prooijen, 2018b), including conspiracy beliefs (e.g., Ballová Mikušková, 2018; Rizeq et al., 2020; Ståhl \& van Prooijen, 2018b) as well as specific coronavirus conspiracy beliefs (Čavojová et al., 2020; Fuhrer \& Cova, 2020). Cognitive reflection is the ability to suspend the first response to a problem and reflect on the problem (Frederick, 2005); therefore, it can help to reflect on the question of correctness and truthfulness of unwarranted information. Similarly, if one is motivated to rational integration, it can lead them to verify information before believing it.

The preference for rational and experiential thinking and the resistance to denominator neglect were examined as predictors of conspiracy beliefs, too, and both of them were associated with conspiracy beliefs only minimally (there were only weak correlations). The preference for rational and experiential thinking was measured by a self-reported inventory, which is not as accurate as a performance test (Ballová Mikušková, Čavojová, et al., 2015); the relation to conspiracy beliefs 
may not be as strong and accurate as the relation of cognitive reflection. However, this was not the case with resistance to denominator neglect. A possible explanation of the weak relation of resistance to denominator neglect (ratio-bias phenomenon) and conspiracy beliefs is that the resistance to denominator neglect as an indicator of increased focusing on relative frequencies of numerators (Garcia-Retamero et al., 2010; Okan et al., 2011; Passerini et al., 2012; Reyna \& Brainerd, 2008) could play a role when the ratios-related information is processed rather than when epistemic accuracy is at stake.

Although there is evidence of the positive effect of analytic cognitive style (present study; Ballová Mikušková, 2018; Orosz et al., 2016; Ståhl \& van Prooijen, 2018; Swami et al., 2014; Swami \& Barron, 2020), of critical thinking (Banziger, 1983; Kowalski \& Taylor, 2009; Manza et al., 2010; Mclean \& Miller, 2010; Stark, 2012; Wilson, 2018) or education (van Prooijen, 2017) on reducing unwarranted beliefs, several studies have also revealed that people with higher analytic and scientific thinking are not always able to interpret information correctly; on the contrary, because of motivated reasoning they interpret the information in favor of their beliefs (Drummond \& Fischhoff, 2017; Kahan, 2012). Moreover, recent research shows that in a time of crisis other factors also affect the endorsement of conspiracy theories: the feeling of uncertainty, powerlessness, anxiety, lack of control or lack of trust (Abalakina-Paap et al., 1999; Freeman et al., 2020; Karić \& Međedović, 2020; Marinthe et al., 2020; Rothmund et al., 2020; Šrol et al., 2021). People turn to conspiracy beliefs when they feel uncertainty, when they feel unsafe, and when they experience lack of (sociopolitical) control and psychological empowerment, and feel powerless and anxious (Douglas, Uscinski, et al., 2019). It follows that just improving analytical thinking cannot protect people from unwarranted beliefs and that negative feelings should be addressed when preparing de-biasing interventions.

The present study was correlational, and although it has a predictive capability, the findings do not explain the relationships revealed. An experimental study should be conducted to examine the effect of the analytic cognitive style and the preference of analytic thinking on the reduction of conspiracy beliefs, as well as the relations among analytic thinking, negative feelings and endorsement of conspiracy theories. Because crises and disasters accompanied by significant changes in society and the lives of individuals are a breeding ground for conspiracy beliefs (Swami et al., 2016; van Prooijen, 2020; van Prooijen \& Douglas, 2017), the need to identify and develop tools and skills to fight unwarranted information is more urgent than ever.

\section{Acknowledgement}

This work was supported by the Slovak Research and Development Agency under contract No. APVV-16-0153.

\section{Author's ORCID}

Eva Ballová Mikušková

https://orcid.org/0000-0002-9162-7735

\section{References}

Abalakina-Paap, M., Stephan, W. G., Craig, T., \& Gregory, W. L. (1999). Beliefs in conspiracies. Political Psychology, 20(3), 637-647. https://doi. org/10.1111/0162-895X.00160

Ballová Mikušková, E. (2015). The denominator neglect in decision-making. Studia Psychologica, 57(4), 255-269. https://doi.org/10.21909/ $\underline{\text { sp. } 2015.03 .698}$ 
Ballová Mikušková, E. (2018). Conspiracy beliefs of future teachers. Current Psychology, 37(3), 692-701. https://doi.org/10.1007/s12144-0179561-4

Ballová Mikušková, E., Čavojová, V., \& Hanák, R. (2015). Self-reported preferred thinking style and cognitive reflection. DuCog: Metacognition and Reasoning. VII Dubrovnik Conference on Cognitive Science, Dubrovnik, 21-23 May, 2015, http://www.cecog.eu/Programme Book 2015. pdf

Ballová Mikušková, E., Hanák, R., \& Čavojová, V. (2015). Appropriateness of two inventories measuring intuition (the PID and the REI). Studia Psychologica, 57(1), 81-100. https://doi. org/10.21909/sp.2015.01.674

Banziger, G. (1983). Normalizing the paranormal: Short-term and long-term change in belief in the paranormal among older learners during a short course. Teaching of Psychology, 10, 212-214. https://doi.org/10.1207/s15328023top1004 6

Barbey, A. K., \& Sloman, S. A. (2007). Base-rate respect: From ecological rationality to dual processes. Behavioral and Brain Sciences, 30, 241-297. https://doi.org/10.1017/S0140525X07001653

Bartlett, J., \& Miller, C. (2010). The power of unreason. Conspiracy theories, extremism and counter-terrorism. Demos.

Bruder, M., Haffke, P., Neave, N., Nouripanah, N., \& Imhoff, R. (2013). Measuring individual differences in generic beliefs in conspiracy theories across cultures: Conspiracy Mentality Questionnaire. Frontiers in Psychology, 4(225), 1-15. https://doi.org/10.3389/fpsyg.2013.00225

Buttler, M., \& Knight, P. (2019). The history of conspiracy theory research: A review and commentary. In J. E. Uscinksi (Ed.), Conspiracy theories and the people who believe them (pp. 33-46). Oxford.

Čavojová, V., Secară, E. C., Jurkovič, M., \& Šrol, J. (2018). Reception and willingness to share pseudo-profound bullshit and their relation to other epistemically suspect beliefs and cognitive ability in Slovakia and Romania. Applied Cognitive Psychology, 33, 299-311. https://doi. org/10.1002/acp.3486

Čavojová, V., Šrol, J., \& Ballová Mikušková, E. (2020). How scientific reasoning correlates with health-related beliefs and behaviors during the
COVID-19 pandemic? Journal of Health Psychology. https://doi.org/10.1177/1359105320962266

Clarke, S. (2002). Conspiracy theory and conspiracy theorizing. Philosophy of the Sciences, 131-150. https://doi.org/10.1177/004931032002001

Douglas, K. M., Sutton, R. M., \& Cichocka, A. (2017). The psychology of conspiracy theories. Current Directions in Psychological Science, 26(6), 538-542. https://doi.org/10.1177/0963721417718261

Douglas, K. M., Sutton, R. M., \& Cichocka, A. (2019). Belief in conspiracy theories: Looking beyond gullibility. In J. P. Forgas \& R. F. Baumeister (Eds.), The social psychology of gullibility: Conspiracy theories, fake news and irrational beliefs (pp. 61-76). Routledge.

Douglas, K. M., Uscinski, J. E., Sutton, R. M., Cichocka, A., Nefes, T., Ang, C. S., Deravi, F., Siang Ang, C., \& Deravi, F. (2019). Understanding conspiracy theories. Political Psychology, 40(S1), 3-35. https://doi.org/10.1111/pops.12568

Drummond, C., \& Fischhoff, B. (2017). Development and validation of the Scientific Reasoning Scale. Journal of Behavioral Decision Making, 30(1), 26-38. https://doi.org/10.1002/bdm.1906

Dyrendal, A., Kennair, L. E. O., \& Lewis, J. R. (2017). The role of conspiracy mentality and paranormal beliefs in predicting conspiracy beliefs among neopagans. International Journal for the Study of New Religions, 8(1), 73-97. https://doi. org/10.1558/ijsnr.36716

Epstein, S. (2003). Cognitive-experiential self-theory of personality. In T. Millon \& M. J. Lerner (Eds.), Comprehensive handbook of psychology, volume 5: Personality and social psychology (Vol. 5, pp. 159-184). Hoboken, NJ: Wiley \& Sons.

Evans, J. S. B. T. (2008). Dual-processing accounts of reasoning, judgment, and social cognition. Annual Review of Psychology, 59, 255-278. https://doi. org/10.1146/annurev.psych.59.103006.093629

Evans, J. S. B. T. (2010). Intuition and reasoning: A dual-process perspective. Psychological Inquiry, 21, 313-326. https://doi.org/10.1080/104784 0X.2010.521057

Frederick, S. (2005). Cognitive reflection and decision making. Journal of Economic Perspectives, 19(4), 2542. https://doi.org/10.1257/089533005775196732

Freeman, D., Waite, F., Rosebrock, L., Petit, A., Causier, C., East, A., Jenner, L., Teale, A. L., Carr, L., Mulhall, S., Bold, E., \& Lambe, S. (2020). Coro- 
navirus conspiracy beliefs, mistrust, and compliance with government guidelines in England. Psychological Medicine. https://doi.org/10.1017/ $\underline{\text { S0033291720001890 }}$

Fuhrer, J., \& Cova, F. (2020). "Quick and dirty": Intuitive cognitive style predicts trust in Didier Raoult and his hydroxychloroquine-based treatment against COVID-19. https://psyarxiv.com/ju62p/

Garcia-Retamero, R., Galesic, M., \& Gigerenzer, G. (2010). Do icon arrays help reduce denominator neglect? Medical Decision Making: An International Journal of the Society for Medical Decision Making, 30(6), 672-684. https://doi. org/10.1177/0272989X10369000

Grzesiak-Feldman, M. (2013). The effect of high-anxiety situations on conspiracy thinking. Current Psychology, 32(1), 100-118. https://doi.org/10.1007/ s12144-013-9165-6

Halama, P. (2019). Construction and psychometric properties of the Epistemologically Unfounded Beliefs Scale. In I. Piterová \& J. Výrost (Eds.), Sociálne procesy a osobnost' 2018. Zborník príspevkov z medzinárodnej konferencie 17. - 19. september 2018, Stará Lesná (pp. 124-133). Spoločenskovedný ústav CSPV SAV.

Imhoff, R., \& Bruder, M. (2014). Speaking (un-) truth to power: Conspiracy mentality as a generalised political attitude. European Journal of Personality, 28(1), 25-43. https://doi.org/10.1002/ per. 1930

Jolley, D., \& Douglas, K. M. (2014). The social consequences of conspiracism: Exposure to conspiracy theories decreases intentions to engage in politics and to reduce one's carbon footprint. British Journal of Psychology, 105, 35-56. https://doi. org/10.1111/bjop.12018

Kahan, D. M. (2012). Ideology, motivated reasoning, and cognitive reflection: An experimental study. SSRN Electronic Journal, 424(107), 407424. https://doi.org/10.2139/ssrn.2182588

Karić, T., \& Međedović, J. (2020). COVID-19 conspiracy beliefs and containment-related behaviour: The role of political trust. https://psyarxiv. com/9kfr8/

Kirkpatrick, L. A., \& Epstein, S. (1992). Cognitive-experiential self-theory and subjective probability: Further evidence for two conceptual systems. Journal of Personality and Social Psychology, 63, 534-544.
Kostovičová, L., Konečný, M., \& Dudeková, K. (2013) Čo to vlastne meriame? Reflexia testu kognitívnej reflexie. Otázniky rozhodovania: teória, empíria, život, 31. medzinárodná konferencia Psychologické dni, 11. - 13. septembra 2013.

Kowalski, P., \& Taylor, A. K. (2009). The effect of refuting misconceptions in the introductory psychology class. Teaching of Psychology, 36, 153-159. https://doi.org/10.1080/00986280902959986

Lantian, A., Muller, D., Nurra, C., \& Douglas, K. M. (2016). Measuring belief in conspiracy theories: Validation of a French and English single-item scale. International Review of Social Psychology, 29(1), 1-14. https://doi.org/10.5334/irsp.8

Manza, L., Hilperts, K., Hindley, L., Marco, C., Santana, A., \& Hawk, M. V. (2010). Exposure to science is not enough: The influence of classroom experiences on belief in paranormal phenomena. Teaching of Psychology, 37, 165-171. https:// doi.org/10.1080/00986283.2010.488554

Marinthe, G., Brown, G., Delouvée, S., \& Jolley, D. (2020). Looking out for myself: Exploring the relationship between conspiracy mentality, perceived personal risk, and COVID-19 prevention measures. British Journal of Health Psychology, June, 25(1), 957-980. https://doi.org/10.1111/ bjhp.12449

McLean, C. P., \& Miller, N. A. (2010). Changes in critical thinking skills following a course on science and pseudoscience: A quasi-experimental study. Teaching of Psychology, 37(2), 37-41. https://doi.org/10.1080/00986281003626714

Okan, Y., Garcia-Retamero, R., Cokely, E. T., \& Maldonado, A. (2011). Individual differences in graph literacy: Overcoming denominator neglect in risk comprehension. Journal of Behavioral Decision Making, 25(4), 390-401. https://doi. org/10.1002/bdm

Orosz, G., Krekó, P., Paskuj, B., Tóth-Király, I., Bőthe, B., \& Roland-Lévy, C. (2016). Changing conspiracy beliefs through rationality and ridiculing. Frontiers in Psychology, 7, 1-9. https://doi.org/10.3389/ fpsyg.2016.01525

Pacini, R., \& Epstein, S. (1999). The relation of rational and experiential information processing styles to personality, basic beliefs, and the ratio-bias phenomenon. Journal of Personality and Social Psychology, 76(6), 972-987. https://doi. org/10.1037/0022-3514.76.6.972 
Pasek, J., Stark, T. H., Krosnick, J. A., \& Tompson, T. (2014). What motivates a conspiracy theory? Birther beliefs, partisanship, liberal-conservative ideology, and anti-black attitudes. Electoral Studies, 40, 482-489. https://doi.org/10.1016/i. electstud.2014.09.009

Passerini, G., Macchi, L., \& Bagassi, M. (2012). A methodological approach to ratio bias. Judgement and Decision Making, 7(5), 602-617.

Pennycook, G., Cheyne, J. A. A., Barr, N., Koehler, D. J., \& Fugelsang, J. A. (2015). On the reception and detection of pseudo-profound bullshit. Judgment and Decision Making, 10(6), 549-563. https://doi.org/10.3389/fpsyg.2013.00279

Pennycook, G., Cheyne, J. A., Seli, P., Koehler, D. J., \& Fugelsang, J. A. (2012). Analytic cognitive style predicts religious and paranormal belief. Cognition, 123(3), 335-346. https://doi.org/10.1016/i. cognition.2012.03.003

Pennycook, G., \& Rand, D. G. (2019). Lazy, not biased: Susceptibility to partisan fake news is better explained by lack of reasoning than by motivated reasoning. Cognition, 188(June), 39-50. https:// doi.org/10.1016/i.cognition.2018.06.011

Pennycook, G., \& Rand, D. G. (2020). Who falls for fake news ? The roles of bullshit receptivity, overclaiming, familiarity, and analytic thinking. Journal of Personality, 88(2), 185-200. https:// doi.org/10.1111/jopy.12476

Pytlik, N., Soll, D., \& Mehl, S. (2020). Thinking preferences and conspiracy belief: Intuitive thinking and the jumping to conclusions-bias as a basis for the belief in conspiracy theories. Frontiers in Psychiatry, 11(September), 1-11. https://doi. org/10.3389/fpsyt.2020.568942

Renard, J.-B. (2020). What causes people to believe conspiracy theories? Diogenes. https://doi. org/10.1177/0392192120945621

Reyna, V. F., \& Brainerd, C. J. (2008). Numeracy, ratio bias, and denominator neglect in judgments of risk and probability. Learning and Individual Differences, 18, 89-107. https://doi. org/10.1016/i.lindif.2007.03.011

Rizeq, J., Flora, D. B., \& Toplak, M. E. (2020). An examination of the underlying dimensional structure of three domains of contaminated mindware: Paranormal beliefs, conspiracy beliefs, and anti-science attitudes. Thinking and Reasoning, 1-25. https:// doi.org/10.1080/13546783.2020.1759688
Rothmund, T., Farkhari, F., Azevedo, F., \& Ziemer, C.-T. (2020). Scientific trust, risk assessment, and conspiracy beliefs about COVID-19 - Four patterns of consensus and disagreement between scientific experts and the German public. https:// psyarxiv.com/4nzuy/

Šrol, J., Ballová Mikušková, E., \& Čavojová, V. (2021). When we are worried, what are we thinking? Anxiety, lack of control, and conspiracy beliefs amidst the COVID-19 pandemic. Applied Cognitive Psychology. https://doi.org/10.1002/acp.3798

Ståhl, T., \& van Prooijen, J. W. (2018). Epistemic rationality: Skepticism toward unfounded beliefs requires sufficient cognitive ability and motivation to be rational. Personality and Individual Differences, 122(1), 155-163. https://doi. org/10.1016/i.paid.2017.10.026

Stanovich, K. E. (2011). Rationality and the reflective mind. Oxford University Press.

Stark, E. (2012). Enhancing and assessing critical thinking in a psychological research methods course. Teaching of Psycholog, 39(2), 107-112. https://doi.org/10.1177/0098628312437725

Stojanov, A., \& Halberstadt, J. (2020). Does lack of control lead to conspiracy beliefs? A meta-analysis. European Journal of Social Psychology, 50(5), 955-968. https://doi.org/10.1002/ejsp.2690

Swami, V., \& Barron, D. (2020). Analytic thinking, rejection of Coronavirus (COVID-19) conspiracy theories, and compliance with mandated social-distancing: Direct and indirect relationships in a nationally representative sample of adults in the United Kingdom. https://osf.io/nmx9w/

Swami, V., Chamorro-Premuzic, T., \& Furnham, A. (2010). Unanswered questions: A preliminary investigation of personality and individual difference predictors of 9/11 conspiracist beliefs. Applied Cognitive Psychology, 24(6), 749-761. https://doi.org/10.1002/acp.1583

Swami, V., Coles, R., Stieger, S., Pietschnig, J., Furnham, A., Rehim, S., \& Voracek, M. (2011). Conspiracist ideation in Britain and Austria: Evidence of a monological belief system and associations between individual psychological differences and real-world and fictitious conspiracy theories. British Journal of Psychology, 102(3), 443-463. https:// doi.org/10.1111/j.2044-8295.2010.02004.x

Swami, V., \& Furnham, A. (2012). Examining conspiracist beliefs about the disappearance of 
Amelia Earhart. The Journal of General Psychology, 139(4), 244-259. https://doi.org/10.1080/00 $\underline{221309.2012 .697932}$

Swami, V., Furnham, A., Smyth, N., Weis, L., Lay, A., \& Clow, A. (2016). Putting the stress on conspiracy theories: Examining associations between psychological stress, anxiety, and belief in conspiracy theories. Personality and Individual Differences, 99, 72-76. https://doi.org/10.1016/i. paid.2016.04.084

Swami, V., Voracek, M., Stieger, S., Tran, U. S., \& Furnham, A. (2014). Analytic thinking reduces belief in conspiracy theories. Cognition, 133(3), 572-585. https://doi.org/10.1016/i.cognition.2014.08.006

Toplak, M. E., West, R. F., \& Stanovich, K. E. (2013). Assessing miserly information processing: An expansion of the Cognitive Reflection Test. Thinking \& Reasoning, 20(2), 147-168. https://doi.org $\angle 10.1080 / 13546783.2013 .844729$

Uscinski, J. E. (2019a). Down the rabbit hole we go! In J. E. Uscinski (Ed.), Conspiracy theories and the people who believe them (pp. 1-32). Oxford.

Uscinski, J. E. (2019b). What is a conspiracy theory? In J. E. Uscinski (Ed.), Conspiracy theories and the people who believe them (pp. 47-52). Oxford.

Uscinski, J. E., \& Paret, J. M. (2014). American conspiracy theories. Oxford University Press.

van Prooijen, J. W. (2017). Why education predicts decreased belief in conspiracy theories. Applied
Cognitive Psychology, 31(1), 50-58. https://doi. org/10.1002/acp.3301

van Prooijen, J. W. (2020). An existential threat model of conspiracy theories. European Psychologist, 25(1), 16-25. https://doi.org/10.1027/1016-9040/ a000381

van Prooijen, J. W., \& Douglas, K. M. (2017). Conspiracy theories as part of history: The role of societal crisis situations. Memory Studies, 10(3), 323-333. https://doi.org/10.1177/1750698017701615

van Prooijen, J. W., \& Song, M. (2020). The cultural dimension of intergroup conspiracy theories. British Journal of Psychology, 1-19. https://doi. org/10.1111/bjop.12471

van Prooijen, J. W., \& van Vugt, M. (2018). Conspiracy theories: Evolved functions and psychological mechanisms. Perspectives on Psychological Science, 13(6), 770-788. https://doi. org/10.1177/1745691618774270

Wilson, J. A. (2018). Reducing pseudoscientific and paranormal beliefs in university students through a course in science and critical thinking. Science \& Education, 27, 183-210. https://doi. org/10.1007/s11191-018-9956-0

Wood, M. J., Douglas, K. M., \& Sutton, R. M. (2012). Dead and alive: Beliefs in contradictory conspiracy theories. Social Psychological and Personality Science, 3(6), 767-773. https://doi. org/10.1177/1948550611434786 